\title{
РАЗВИТИЕ МЛАДШИХ ШКОЛЬНИКОВ НА УРОКАХ ЛИТЕРАТУРНОГО ЧТЕНИЯ ЧЕРЕЗ ПРОЕКТНУЮ ДЕЯТЕЛЬНОСТЬ
}

\section{DEVELOPMENT OF YOUNGER PUPILS IN LITERARY READING LESSONS THROUGH PROJECT ACTIVITIES}

\section{Sokorutova}

Summary: The article discusses the pedagogical conditions for the effective development of the creative abilities of primary schoolchildren on the basis of project activities. The foundations of the development of creative abilities, the historical prerequisites of project activities, the peculiarities of the formation of creative abilities are revealed. A project activity has been developed at the lessons of literary reading in grade 3 for the development of the creative abilities of primary schoolchildren, including the content, goals, means and methods of their implementation in the educational process.

Keywords: junior schoolchild, project, creativity, experiment, project activity.
A ктуальность исследования заключается в том, что в настоящее время всё более значимым становится использование в образовательном процессе приёмов и методов, которые формируют умение самостоятельно добывать знания, собирать необходимую информацию, умение выдвигать гипотезы, делать выводы и умозаключения.

Овладение учащимися проектной деятельностью позволяет более успешно реализовать задачи развития младших школьников: формирования приемов умственной деятельности, адекватной трудовой мотивации, гностических умений, становления их субъектной позиции в учебной деятельности и др.

Анализ научной литературы свидетельствует о проблеме повышения качества обучения, использовании нетрадиционных педагогических технологий, способствующих развитию творческой личности уже на начальном этапе школьного обучения.

Процесс развития творческих способностей у младших школьников на уроках литературного чтения в процессе реализации проектов будет протекать наиболее эффективно, при соблюдении следующих педагогических условий:

- понимать под проектной деятельностью совместную учебно-познавательную деятельность педагога и учащихся по проектированию и реализации

\author{
Сокорутова Людмила Владимировна \\ К.п.н., дочент, Северо-Восточный \\ федеральный университет \\ sok.lyda@mail.ru
}

Аннотация: В статье рассмотрены педагогические условия эффективного развития творческих способностей младших школьников на основе проектной деятельности. Раскрыты основы развития творческих способностей, исторические предпосылки проектной деятельности, особенности формирования творческих способностей. Разработана проектная деятельность на уроках литературного чтения в 3 классе для развития творческих способностей младших школьников, включающая в себя содержание, цели, средства и способы их реализации в учебном процессе.

Ключевые слова: младший школьник, проект, творческие способности, эксперимент, проектная деятельность.

индивидуального или коллективного исследования, направленную на решение личностно-значимой творческой задачи и создание конкретного продукта;

- разработать содержание и этапы обучения младших школьников проектной деятельности с учётом возрастных особенностей детей и доступных форм ее организации в начальной школе;

- в качестве основного условия эффективной организации проектной деятельности выделить необходимость изменения профессиональной позиции педагога от руководителя, предъявляющего проектные задания, к участнику и организатору совместной проектно-исследовательской деятельности с младшими школьниками [3].

В соответствии с целью исследования определены следующие задачи:

1. Провести теоретический анализ учебной проектной деятельности младших школьников, уточнить понятие "творческие способности» и ее место В структуре учебной проектной деятельности младших школьников.

2. Выявить психолого-педагогические условия обучения младших школьников решению проектной деятельности посредством творческих способностей младших школьников, рассмотрев содержание, принципы, методы и формы организации данного процесса на уроках литературного чтения. 
3. Обосновать понятие «проектная деятельность как средство развития творческих способностей», раскрыть его содержание и выявить показатели и уровни развития творческих способностей.

4. Разработать комплекс проектов, средства и способы ее реализации на уроках литературного чтения в начальных классах.

5. Проследить динамику и уровень влияния проектной деятельности на развитие творческих способностей младших школьников на уроках литературного чтения.

Теоретико-методологическую основу исследования составили: идеи концепции целостности и системности педагогических явлений и процессов (ВП Беспалько, ИЯ Лернер, ВС Ильин и др.), положения теории личностного развития (Л.И. Божович, М.Р. Гинзбург, К. Левин, А. Маслоу, Л.М. Митина, Г. Олпорт, Е.Л. Яковлева и др.),теория субъектно-деятельностного подхода в обучении (Н.М. Борыло, А.Н. Леонтьев, С.Л. Рубинштейн, Н.К. Сергеев и др ), теоретические основы концепции личностно ориентированного образования (В.В. Сериков, Е.В. Бондаревская, В.В. Зайцев, Е.А. Крюкова), концепции самореализации личности (А. Маслоу, А.К. Исаев, Г.К. Чернявская, Л.А. Коростылева, А.А. Идинов, Е.И. Горячева и др ) [5].

Экспериментальной базой исследования явилась МОБУ «Средняя общеобразовательная школа №29» г. Якутска (с углубленным изучением отдельных предметов), 3 «б» и 3 «а» классы, учительница Сафонова Дарья Власьевна. В исследовании приняли участие 52 учащихся младшего школьного возраста.

\section{Этапы исследования:}

Первый этап - изучение и теоретический анализ литературы по проблеме исследования; определение цели и задач, исходной гипотезы исследования, формулирование положений, выносимых на защиту; проведение констатирующего этапа эксперимента; выявление и теоретическое обоснование творческих способностей младших школьников.

На втором этапе проводилась реализация проектной деятельности по развитию творческих способностей младших школьников на уроках литературного чтения на примере 3 класса.

Третий этап - изучение уровня сформированности творческих способностей младших школьников после формирующего этапа опытно-экспериментальной работы, оценка, обобщение и анализ результатов проведенного исследования.

В ходе выполнения работы выявлены и экспериментально апробированы педагогические условия эффек- тивного развития творческих способностей младших школьников на основе проектной деятельности; разработана проектная деятельность на уроках литературного чтения в 3 классе для развития творческих способностей младших школьников, включающая в себя содержание, цели, средства и способы их реализации в учебном процессе.

Практическая значимость заключается в том, что разработанная проектная деятельность и выявленные психолого-педагогические условия ее эффективной реализации в учебной деятельности младших школьников дают возможность развитию творческих способностей учащихся начальных классов. Обоснованные в исследовании принципы, содержание, технология, средства развития творческих способностей младших школьников на уроках литературного чтения оказывают содействие в решении задач модернизации содержания образования - приданию процессу обучения деятельностного характера и личностно ориентированной направленности, прямо отвечают современным и перспективным задачам педагогической практики, так как направлены на формирование творческой личности[2].

Целью развития творческих способностей является общее развитие и формирование качеств творческой личности учеников, которая может быть достигнута благодаря созданию условий разнообразной деятельности для выявления и развития способностей детей.

Для достижения цели необходимо решить следующие задачи:

- включить детей в разнообразную деятельность;

- выработать гибкие умения, позволяющие детям быстро осваивать новые виды труда (деятельности), т.е. перенос знаний и навыков;

- развивать сообразительность и быстроту реакций при решении новых различных задач, связанных с практической деятельностью.

Таким образом, развитие творческих способностей младших школьников заключается в следующих особенностях:

- приобретение произвольности, предполагающей создание замысла, его планирование и реализацию;

- становится особой деятельностью, превращаясь в фантазирование;

- ребёнок осваивает приёмы и свойства создания образов;

- в связи с переходом во внутренний план, отпадает необходимость в наглядной опоре для создания образов.

При этом целенаправленно и в массовом масштабе способствовать развитию широкого спектра способно- 
стей детей может только учебное учреждение, дающее ребёнку возможность проявить себя в активной деятельности широкого диапазона и наиболее эффективный путь развития способностей через приобщение детей к продуктивной творческой деятельности.

Одна из главных задач педагога по мнению Н.Е. Веракса при организации проектной деятельности младших школьников заключается в том, чтобы поддерживать детскую инициативу. Инициатива ребенка в себя включает творческий компонент. Творческая инициатива проявляется всякий раз, когда ребенок начинает решать свою собственную задачу, а не ту задачу, которую поставил перед ним педагог. Умение создавать условия для проявления творческой инициативы младших школьников является важным моментом готовности педагога к организации проектной деятельности [4].

Проведен констатирующий этап опытно-экспериментальной работы. Рассмотрена проведенная работа по диагностике уровня развития творческих способностей младших школьников МОБУ СОШ №29.

Проанализированы данные диагностики по определению уровня развития творческих способностей младших школьников в экспериментальной и контрольной группе.

Нами использовались следующие методики:

- методика «Тест креативности» Е. Торренса;

- методика «Опросник креативности» Д. Джонсона.

Проведя методики диагностики развития творческих способностей детей младшего школьного возраста Е.П. Торренса (в адаптации Е.Е. Туник) мы получили результаты, представленные в рисунке 1.

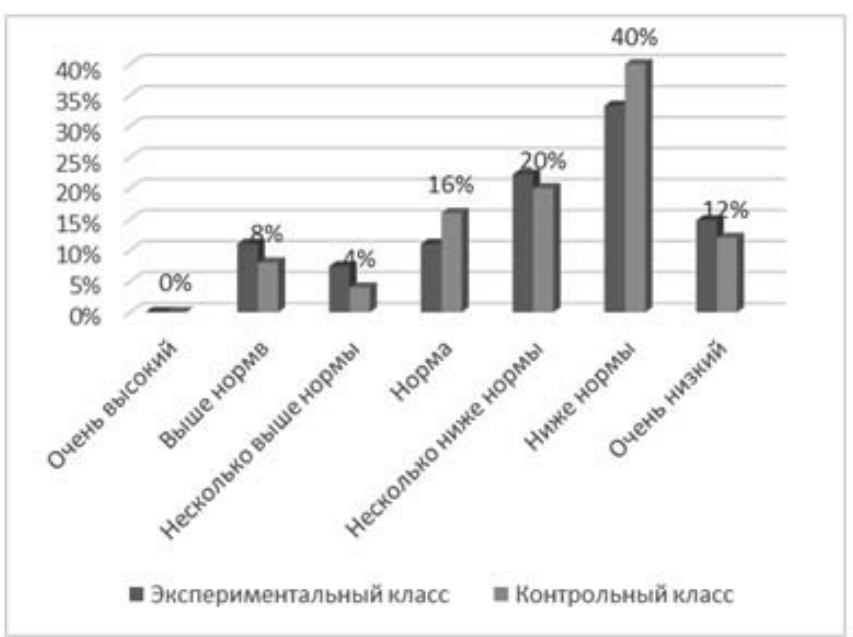

Рис. 1. Уровень сформированности творческих способностей

По итогам проведенной диагностики уровня развития творческих способностей младших школьников разработаны и проведены проекты, а также реализованы педагогические условия по развитию творческих способностей младших школьников посредством проектной деятельности.

На формирующем этапе экспериментального исследования была организована работа по литературному чтению в 3 классе, направленная на развитие творческих способностей посредством проектной деятельности.

Таблица 1

Проекты на уроках литературного чтения

\begin{tabular}{|c|c|c|}
\hline Название проектов. & Продукт & Планируемые результаты. \\
\hline 1.«Страницы большой жизни» & $\begin{array}{l}\text { презентация, индивидуальное сообщение } \\
\text { «Страницы большой жизни», иллюстрация, интервью. }\end{array}$ & $\begin{array}{l}\text {-ученики приобщаются с книгой и чтением, } \\
\text { поиском информации; } \\
\text {-соприкасаются с жизнью и творчеством } \\
\text { писателей-классиков, тем самым само } \\
\text { реализовывая творческие способности; }\end{array}$ \\
\hline 2.«Поэты Северного края». & $\begin{array}{l}\text { разработанные мероприятия (проекты) детей для 1,2 } \\
\text { классов, выставка иллюстраций. }\end{array}$ & $\begin{array}{l}\text {-изучают якутскую литературу, изучают ее. } \\
\text { Соприкасаются с жизнью и творчеством } \\
\text { поэтов Севера, тем самым самореализовывая } \\
\text { творческие способности. }\end{array}$ \\
\hline $\begin{array}{l}\text { 3.Конкурс чтецов } \\
\text { к Дню Республики Саха (Якутия). }\end{array}$ & $\begin{array}{l}\text { проект на сайте Региональное правительство РШБА } \\
\text { в Якутии: }\end{array}$ & $\begin{array}{l}\text {-повышение читательского интереса; } \\
\text {-развитие культуры и творчества учеников; }\end{array}$ \\
\hline 4.«Книжный бум» & $\begin{array}{l}\text { «Авторская книжка-самоделка» } \\
\text {-Создание собственной авторской красочно иллюстри- } \\
\text { рованной книжки о Великой Отечественной войне в } \\
\text { любой форме, из любых материалов, в любом жанре: } \\
\text { рассказ, сказка, стихотворения, занимательная книга, } \\
\text { справочник. }\end{array}$ & $\begin{array}{l}\text {-знают истории своих предков - участников войны; } \\
\text {-знают историю, которые хранятся в их семьях; } \\
\text {-поддерживают связь поколений; } \\
\text {-сохраняют память о войне и людях, которые отво- } \\
\text { евали мир и одержали победу; }\end{array}$ \\
\hline 5.«Живая память поколений» & $\begin{array}{l}\text { «Документальная мультимедийная книга» } \\
\text { «Авторская мультимедийная книга». }\end{array}$ & $\begin{array}{l}\text {-сохраняют память } 0 \text { войне и людях, которые отво- } \\
\text { евали мир и одержали победу. }\end{array}$ \\
\hline
\end{tabular}


Нами были разработаны 5 проектов на уроках литературного чтения, отражены в таблице.

В итоге формирующего этапа эксперимента мы получили:

1. Презентацию, сообщение, иллюстрация «Страницы большой жизни», посвященная писателям-юбилярам 2019 года: Виктор Петрович Астафьев - 95 лет, Анна Ахматова -130 лет, Александр Сергеевич Пушкин - 220 лет, Всеволод Михайлович Гаршин- 165 лет, Антон Павлович Чехов- 160 лет.

2. Мероприятие, выставка иллюстраций «Поэты Северного края»: Иван Михайлович Гоголев, «Ыңырар уоттар» (Зовущие огни), «Хотугу сибэкки» (Цветок Севера), «Өлүөнэ сарсыардата» (Утро Лены), «Саллаат сүрэбэ» (Сердце солдата), Владимир Михайлович Новиков, сборник стихов «Уһуктубут кыраайга» (В пробуждённом крае); Николай Саввич Тарабукин (эвенский советский писатель и поэт, основоположник эвенской младописьменной литературы), сборники стихов «Песни тайги» (1936); Семен Петрович Данилов, сборники его стихов «Мин дойдум» (Моя родина), «Эйэлээх куорат» (Мирный город), «Күн таммақа» (Брызги солнца), «Белая ночь», «Белый конь Манчары».

3. Стихотворения: «Мой Якутск», «Родина моя», «Якутия», «Мой край», «Серебро Якутии», «Дивный край», «Река Лена», «Мой город» итд.

4. Иллюстрированная книжка о Великой Отечественной войне «Авторская книжка-самоделка».

5. Сочинение «Документальная мультимедийная книга», «Авторская мультимедийная книга».

Результат показал, что большинство младших школьников качественно справились с заданием. В ходе выполнения проекта были достигнуты поставленные цели. Данная работа сплотила учеников, заинтересовала их поиском новой информации, расширила кругозор уча- щихся, положила основу для формирования исследовательских навыков и познавательного интереса, способствовала развитию навыков работы в коллективе, умения находить и совместно исправлять ошибки, умения отстаивать свою точку зрения и находить компромиссы.

На контрольном этапе были проведены методики, с целью выявления изменений в развитии творческих способностей младших школьников. Данные фиксировались, сравнивались с первоначальными результатами, что позволило получить сопоставленный материал и установить эффективность методик.

На этом этапе использовались те же методики и обследование, что и на констатирующем этапе, для сопоставления результатов обследования испытуемых.

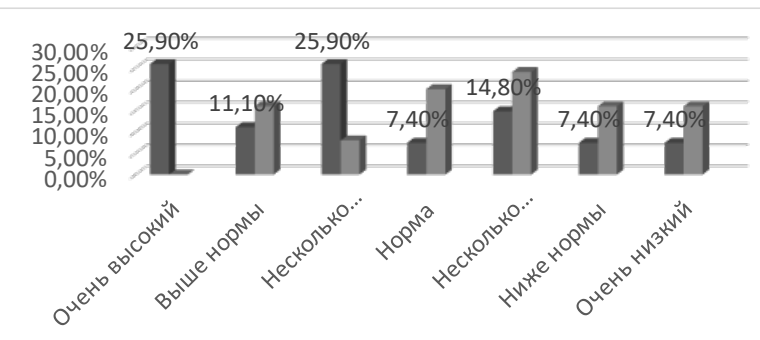

Рис. 2. Результаты обследования испытуемых

Доказано, что предложенная проектная деятельность способствует успешному развитию творческих способностей младших школьников.

Технология проектной деятельности украшает и вносит разнообразие в процесс обучения, кроме того, что данная работа позволяет детям более успешно осваивать материал, благодаря своему насыщенному и интересному содержанию, она также облегчает работу учителя, которому проще и интересней работать с детьми, которые заинтересованы и увлечены деятельностью.

\section{ЛИТЕРАТУРА}

1. Бухаркина М.Ю. Разработка учебного проекта [Текст] / М.Ю. Бухаркина. - М., 2003. - 140 с.

2. Горенков Е.М. Учебные проекты в начальной школе [Текст] / Е.М. Горенков. - М., 2012. - 127 с. - ISBN 5-210-00125-3.

3. Иванова Н.В. Методика применения проектной деятельности в начальной школе [Текст] / Н.В. Иванова // Начальная школа. - 2004. - № 2. - С. 125. - ISBN 5-210-00125-3.

4. Кукушин В.С. Современные педагогические технологии. Начальная школа. Пособие для учителя [Текст] / В.С. Кукушкин. - Ростов н/Д: изд-во «Феникс», 2003. - 384 c. - ISBN 5-210-00125-3.

5. Сафонова Д.В., Сокорутова Л.В. Проектная деятельность младших школьников при изучении волшебных сказок на уроках литературного чтения // Педагогика. Образование. Практика. Под редакцией А.В. Оконешниковой. 2019. Киров -103 с.

6. Ступницкая М.А. Что такое учебный проект? [Текст] / М.А. Ступницкая. - М.: Первое сентября, 2010. - 44 с. - ISBN 5-210-00125-3.

7. Учебные проекты: возможности Интернет. Бухаркина М. Ю.// Сборник докладов научно-практической конференции «Глобальные телекоммуникации в образовании». - М., 2006. - 193 с. - ISBN 5-210-00125-3.

(c) Сокорутова Людмила Владимировна (sok.lyda@mail.ru). Журнал «Современная наука: актуальные проблемы теории и практики» 